\title{
Internalisasi Nilai-Nilai Keagamaan Dalam Membentuk Komunikasi Keluarga Islami di Era Digital
}

\author{
Ditha Prasanti, Kismiyati El Karimah \\ Universitas Padjadjaran \\ dithaprasanti@gmail.com
}

\begin{abstract}
Abstrak
Penelitian ini bertujuan untuk mengetahui Internalisasi Nilai-Nilai Keagamaan dalam Membentuk Komunikasi Keluarga Islami di era Digital. penelitian ini, menggunakan metode penelitian kualitatif studi kasus. Teknik pengambilan data adalah observasi partisipatoris, wawancara mendalam, dan penelusuran dokumentasi dari berbagai sumber yang terkait. Hasil penelitian menunjukkan adanya upaya internalisasi nilai-nilai keagamaan dalam membentuk komunikasi keluarga yang islami di era digital yang terdiri dari: 1) Peran orangtua sebagai komunikator, sangat dominan dalam pola komunikasi keluarga yang islami; 2) Nilai-nilai keagamaan yang ditanamkan dalam keluarga islam melalui konteks pesan verbal dan non verbal, mulai dari pendidikan, kesehatan, pergaulan, dan gaya hidup yang islami; 3) Adanya penggunaan media sosial Whatsapp Group dalam menyebarkan pesan yang berisi nilai-nilai religi tersebut kepada anggota keluarga lainnya.
\end{abstract}

Kata Kunci: Nilai Keagamaan, Komunikasi, Keluarga, Islami, Era Digital

\begin{abstract}
This study aims to determine Internalization of Religious Values in Shaping Islamic Family Communications in the Digital Era". In this study, the authors use qualitative research method of case study. The data collection techniques used are participatory observation, in-depth interviews, and documentary tracking from various related sources. The result of the research shows that there is an effort to internalize religious values in shaping the Islamic family communication in this digital era which consists of: (1) The role of parent as communicator, very dominant in the pattern of family communication that is Islamic; (2) religious values embedded in Islamic families through the context of verbal and non verbal messages, ranging from education, health, association, and Islamic lifestyle; (3) The existence of social media use Whatsapp Group in spreading the message containing religious values to other family members.
\end{abstract}

Keywords: Religious Value, Communication, Family, Islami, Digital Era

Permalink/DOI: http://dx.doi.org/10.18326/infsl3v12i1.195-212 


\section{Pendahuluan}

Nilai-nilai keagamaan menjadi hal yang penting untuk dipelajari dan dipraktekkan dalam kehidupan sehari-hari. Tak dapat dipungkiri, bahwasanya nilai keagamaan inilah yang juga dapat tercermin dari proses komunikasi yang terjalin antar individu satu sama lainnya. Tetapi, pada dasarnya, kita akan memperoleh nilai-nilai keagamaan tersebut dari ajaran dalam interaksi dengan keluarga. Komunikasi keluarga sebagai salah satu proses yang dapat mengajarkan nilainilai keagamaan bagi generasi penerusnya. Struktur keluarga terkecil yang terdiri dari ayah, ibu, dan anak inilah, menjadi pondasi dasar dalam mewujudkan komunikasi keluarga yang islami.

Setiap keluarga tentu memiliki cara tersendiri dalam memaknai tentang internalisasi nilai-nilai keagamaan ini. Apalagi saat ini, era nya telah berubah, era digital telah membuat proses komunikasi keluarga pun menjadi berubah. Era digital pun memberikan dinamika proses komunikasi keluarga yang baru, dengan kehadiran media digitalnya.

Penulis melihat urgensi untuk melakukan penelitian ini, bercermin pada beberapa penelitian terdahulu. Dalam penelitian yang telah dilakukan oleh Wijayanti, dkk (2015) tentang Pola Komunikasi Keluarga dalam membangun Akhalakul Karimah, dikatakan bahwa keluarga sebagai lembaga sosial yang khas karena dalam keluarga anggotanya terdiri dari individu-individu yang mempunyai hubungan darah sangat erat, tetapi juga merupakan bagian dari masyarakat yang lebih besar. Di samping itu, keluarga berkembang dalam semua lapisan masyarakat, masyarakat dapat memperoleh dukungan yang diperlukan dari anggota keluarga, sebaliknya keluarga hanya dapat bertahan kalau didukung oleh masyarakat yang lebih luas (Wijayanti: 2015).

Membiasakan ibadah pada anak tentu tidak bisa terlepas dari bagaimana orang tua dapat membangun pola komunikasi yang tepat, agar anak merasa enjoy dalam melaksanakan ibadahnya. Komunikasi antara ayah dan ibu dapat menjadi panutan bagi anakanaknya dalam berkomunikasi pada siapapun, komunikasi antar saudara dalam keluarga dapat memberi rasa aman dan percaya diri pada masing-masing. Pola komunikasi keluarga dalam membiasakan 
anak beribadah perlu diteliti beberapa keluarga yang telah berhasil mendidik anak-anaknya, sehingga menjadi anak yang berakhlak mulia (akhlaqul kharimah). Keluarga akan menjadi tempat mencari informasi-informasi tentang komunikasi yang dilakukan antar anggota keluarga dalam membiasakan anak-anaknya beribadah sesuai syariah (Wijayanti: 2015).

Di samping itu, perlu diketahui juga bahwa kedudukan utama setiap keluarga adalah fungsi pengantara anggotanya pada masyarakat yang lebih besar, sebagai penghubung pribadi dengan struktur sosial yang lebih besar. Keluarga dapat membantu keberlangsungan masyarakat dengan mengambil beberapa tugas untuk mengantarkan anggota keluarganya memasuki tempat yang lebih besar. Sebuah masyarakat besar tidak akan bisa bertahan apabila kebutuhannya yang bermacam-macam tidak terpenuhi, misalnya regenerasi, proses produksi, pembagian makanan, perlindungan anak, persamaan hukum, pengembangan generasi muda dalam kehidupan sosial (Goode, 2007: 7).

Keluarga mewakili suatu konstelasi hubungan yang sangat khusus. Definisi hukum dari keluarga adalah sekelompok orang yang terikat oleh darah, perkawinan dan adopsi. Menurut Galvin dan Brommel (dalam Tubss dan Moss, 2008:215) mendefinisikan keluarga adalah jaringan orang-orang yang berbagi kehidupan mereka dala jangka waktu yang lama; yang terikat perkawinan, darah, atau komitmen, legal atau tidak; yang menganggap diri mereka sebagai keluarga; dan yang berbagi pengharapanpengharapan masa depan mengenai hubungan yang berkaitan. Keluarga dipandang sebagai sebuah sistem, menekankan hubunganhubungan keluarga ketimbang anggota-anggota perseorangan. Pemahaman atas keluarga seperti ini, sebagai suatu keseluruhan ketimbang sebagai sejumlah anggota perseorangan, mengalihkan perhatian ke pola-pola hubungan dan siklus-siklus perilaku alihalih sebab dan akibat. Setiap anggota mempengaruhi orang-orang lainnya tapi pada gilirannya dipengaruhi oleh mereka (Bocher dan Eisenberg dalam Tubss dan Moss, 2008:215).

Lain halnya dengan penelitian yang dilakukan penulis. Penulis melihat komunikasi keluarga sebagai proses komunikasi 
yang dialami oleh setiap individu dalam kehidupan keluarganya. Setiap keluarga yang baik tentu ingin memberikan pendidikan dan pengasuhan yang terbaik bagi anak-anaknya. Hal inipun terwujud dengan dilandasi nilai-nilai keagamaan dalam proses komunikasi keluarga tersebut. Agama tentu menjadi pondasi utama, tidak hanya dalam komunikasi keluarga, tetapi dalam setiap aspek kehidupan manusia. Pada era digital ini, setiap keluarga pun memiliki cara tersendiri dalam membangun nilai-nilai keagamaan yang terjalin melalui proses komunikasi keluarga yang islami. Oleh karena itu, penulis mengangkat penelitian ini dengan judul "Internalisasi NilaiNilai Keagamaan dalam Membentuk Komunikasi Keluarga Islami di era Digital".

\section{Internalisasi Nilai-Nilai Keagamaan}

Penelitian terdahulu yang lain tentang internalisasi nilai keagamaan, juga dilakukan oleh Supriyatno (2012) yang berjudul "Model Internalisasi Nilai-Nilai Keagamaan di Ma'had Sunan Ampel Al-Ali UIN Malang”. Internalisasi yang dimaksud dalam penelitian ini adalah suatu proses yang dialami seseorang dalam menerima dan menjadikan bagian milik dirinya pelbagai sikap, cara mengungkapkan perasaan atau emosi, pemenuhan hasrat, keinginan, nafsu, keyakinan, norma-norma, nilai-nilai, sebagaimana yang dimiliki individu-individu lain dalam komunitasnya.

Nilai keagamaan yang dimaksud dalam penelitian Supriyatno (2012) adalah keimanan, ketaqwaan, kesabaran, kezuhudan, kemauan kerja keras, optimis, serta mandiri mahasiswa yang tinggal di ma'had sunan ampel al-'ali UIN Malang. Dalam penelitian ini, istilah vektor percepatan internalisasi nilai keagamaan dilukiskan sebagai apa yang mempercepat dan bagaimana arah percepatan terjadinya proses internalisasi nilai-nilai keagamaan tadi. Prinsip berarti dasar, azas, asal usul. Sesuatu yang menjadi asal usul/ dasar terjadinya hal-hal lain; azas atau dasar terjadinya hal-hal lain.

Jika dikaitkan dengan levels of knowledge, prinsip merupakan kaitan dua konsep yang membentuk suatu pengertian baru. Jika dikaitkan dengan logika dalam proses penalaran, prinsip 
menggunakan logika "jika - maka". Dengan demikian prinsip dimaknai sebagai azas atau dasar munculnya pengetahuan dan pemikiran lebih lanjut.

Diding Nurdin (1999) menemukan bahwa perilaku, sifat, dan gaya kepemimpinan kyai memainkan peranan penting dalam membentuk kepribadian muslim. Karakteristik keagamaan tumbuh dari dalam diri manusia dalam rangsanganrangsangan lingkungan pertumbuhan yang kondusif mendukungnya. Aspek kemauan manusia untuk menumbuhkan sifat-sifat tersebut menjadi masalah yang sentral.

Jika dikaitkan dengan psikologi perkembangan, internalisasi berkaitan dengan tahaptahap perkembangan manusia. Setiap tahap perkembangan manusia mempunyai tugas-tugas perkembangan secara khas yang berbeda dengan tahap perkembangan makhluk lainnya. Proses internalisasi berjalan sesuai dengan tugas-tugas setiap tahap perkembangan. Proses internalisasi pada masa bayi dan awal anak-anak berbeda dengan akhir masa kanak-kanak, masa remaja, masa usia pertengahan, dan masa tua. Internalisasi menjadi tekanan sentral pada proses pempribadian. Sedangkan pempribadian menurut Carkhuff (1983:113), merupakan dimensi kritis pada perolehan atau perubahan diri manusia. Pempribadian termasuk pempribadian makna (nilai) atau implikasi respons terhadap makna. Personalisasi dan internalisasi secara langsung akan mengarahkan pada suatu tujuan, mengembalikan perasaan baru, membantu mempersonalisasi makna, masalah, dan tujuan. Personalisasi membantu pemahaman dan membantu seseorang untuk bertindak (Supriyatno: 2012).

\section{Pola Komunikasi Keluarga}

Salah satu hasil penelitian tentang komunikasi keluarga, juga menyebutkan adanya bentuk komunikasi dalam keluarga menurut Novianti (2013:24-25), antara lain, yaitu: 1) Komunikasi verbal. Komunikasi merupakan suatu kegiatan antara individu atau kelompok yang mempergunakan bahasa sebagai alat perhubungan. Kegiatan komunikasi verbal menempati frekuensi terbanyak dalam 
keluarga. Setiap hari orang tua selalu ingin berbincang-bincang kepada anaknya. Dalam perhubungan antara orang tua dan anak akan terjadi interaksi; 2) Komunikasi non verbal. Komunikasi non verbal suatu ketika bisa berfungsi sebagai penguat komunikasi verbal. Komunikasi non verbal terasa jika secara verbal tidak mampu mengungkapkan sesuatu secara jelas. Mark L. Knapp, menyebutkan ada lima macam fungsi pesan non verbal, yaitu : a) Repetisi, mengulang kembali gagasan yang sudah disajikan secara verbal; b) Subtitusi, mengantikan lambang-lambang verbal; c) Kontradiksi, menolak pesan verbal atau memberikan makna yang lain terhadap pesan verbal; d) Komplemen, melengkapi dan memperkaya makna pesan nonverbal; e) Aksentuasi, menegaskan pesan verbal atau menggarisbawahinya (Djamarah, 2004:44);

3) Komunikasi individual. Komunikasi individual atau komunikasi interpersonal adalah komunikasi yang sering terjadi dalam keluarga. Komunikasi yang terjadi berlangsung dalam sebuah interaksi antarpribadi; antara suami dan istri, antara ayah dan anak, antara ibu dan anak, dan antar anak dan anak; dan 4) Komunikasi kelompok, hubungan akrab antara orang tua dan anak sangat penting untuk dibina dalam keluarga. Sebenarnya, pertemuan anggota keluarga untuk duduk bersama dalam satu waktu dan kesempatan, sangat penting sebagai simbol keakraban keluarga.

Sementara, jika dikaji dari hasil penelitian yang telah dilakukan Wijayanti (2015) menunjukkan bahwa prinsip-prinsip komunikasi dalam Alqur'an seperti qaulan baliga, qaulan karima, qaulan maisura, qaulan ma'tuf, qaulan layyina, dan qaulan sadida sudah diterapkan dalam keluarga-keluarga yang dijadikan informan dalam penelitian ini dengan pola komunikasi gabungan antara verbalnon verbal dan individu-kelompok. Akan tetapi, dalam aplikasinya setiap keluarga memiliki kekhasan masing-masing sesuai dengan situasi, latar belakang budaya, tingkat pemahaman keagamaan, dan sebagainya. Pada akhirnya, harapan akan perilaku anak yang memiliki sifat akhlakul karimah, akan ditentukan oleh anak-anak itu sendiri. Akan tetapi, keluarga, sebagai lingkungan pertama si anak memiliki peran yang sangat penting dalam membentuknya. Dalam proses pembentukan ini, pola komunikasi yang digunakan dalam keluarga memegang peranan yang sangat penting. 
Berdasarkan beberapa gambaran dari hasil penelitian terdahulu tentang internalisasi nilai-nilai keagamaan dan pola komunikasi keluarga yang berlandaskan Alqur'an, penulis pun semakin tertarik untuk melihat internalisasi nilai-nilai keagamaan dalam membentuk komunikasi keluarga yang islami di era digital ini.

\section{Metode Penelitian}

Metode penelitian yang digunakan penulis dalam penelitian ini adalah metode penelitian studi kasus. Mulyana (2008: 201) menyatakan bahwa "studi kasus merupakan uraian dan penjelasan komprehensif mengenai berbagai aspek seorang individu, suatu kelompok, atau organisasi (komunitas), suatu program, atau suatu situasi sosial". Penelitian studi kasus berupaya menelaah sebanyak mungkin data mengenai subjek yang diteliti. Dalam hal ini, data tersebut dimungkinkan didapatkan melalui wawancara mendalam, pengamatan, penelaahan dokumen hasil survey, dan data apa pun untuk menguraikan suatu kasus secara terperinci.

Menurut Yin (2002), studi kasus dapat dibagi ke dalam singlecase dan multiple-case. "Single-case digunakan jika kasus yang diteliti itu merupakan kasus yang ekstrim atau unik, memenuhi semua kondisi untuk menguji teori-teori yang ada, memiliki kesempatan untuk mengobservasi dan menganalisa fenomena yang sebelumnya tidak diselediki secara ilmiah, sedangkan multiple-case memungkinkan dilakukannya perbandingan di antara beberapa kasus" (Yin, 2002: 46-48). Dalam penelitian yang dilakukan peneliti, peneliti menggunakan single-case study design. Studi kasus, sebagai suatu metode kualitatif, mempunyai beberapa keuntungan. Menurut Lincoln dan Guba yang dikutip Mulyana (2008: 201),

\section{Teknik Pengumpulan Data}

Proses pengumpulan data yang dilakukan dalam penelitian ini; 1) Wawancara, Salah satu sumber informasi studi kasus yang sangat penting adalah wawancara (Yin, 2002: 108). Susan Stainback (dalam Sugiyono, 2005: 72) mengemukakan bahwa dengan 
wawancara, maka peneliti akan mengetahui hal-hal yang lebih mendalam tentang partisipan dalam menginterpretasikan situasi dan fenomena yang terjadi, di mana hal ini tidak bisa ditemukan melalui observasi.

Penelitian ini menggunakan teknik wawancara sebagai metode pengumpulan data penelitian kepada informan penelitian yang melakukan internalisasi nilai-nilai keagamaan dalam membentuk komunikasi keluarga islami, khususnya dengan menggunakan peran media sosial. 2) Observasi, Selain wawancara mendalam dan FGD, dalam penelitian ini juga akan dilakukan observasi laangsung untuk memperoleh data yang lebiah komprehensif. Melalui observasi, peneliti mempelajari tentang perilaku dan makna yang menempel pada perilaku-perilaku tersebut. Metode observasi adalah metode pengumpulan data yang digunakan untuk menghimpun data penelitian melalui pengamatan dan penginderaan (Bungin, 2007:115). 3) Dokumentasi, penelitian ini juga akan menggunakan dokumentasi sebagai alat pengumpulan data. Dokumentasi berupa berkas-berkas penting mengenai internalisasi nilai-nilai keagamaan dalam membentuk komunikasi keluarga islami di era digital.

Tujuan studi kasus adalah untuk memberikan gambaran secara mendetail tentang latar belakang, sifat-sifat serta karakterkarakter yang khas dari kasus, ataupun status dari individu yang bersangkutan, dan sifat-sifat khas di atas akan dijadikan suatu hal yang bersifat umum (Nazir, 2003: 66). Studi kasus bersifat holistik. Metode ini menganggap kasus sebagai entitas menyeluruh dan bukan sebagai kumpulan bagian-bagian atau kumpulan skor mengenai variabel (Ragin dalam Mulyana, 2008: 203).

\section{Informan Penelitian}

Dalam penelitian ini, penulis menggunakan teknik sampling purposive, yaitu memilih informan sesuai dengan kriteria kebutuhan penelitian. Penulis mengambil 4 orang informan yang sesuai dengan penelitian ini, yaitu, Ns, mahasiswa sarjana, asal Cilegon, Cn, pegawai bank, asal Tasikmalaya, Sn, pengajar, asal Bandung, Jys, pegawai negeri, asal Cilegon 


\section{Hasil Dan Pembahasan}

Berbicara tentang internalisasi nilai-nilai keagamaan, penulis juga menyimak adanya penelitian terdahulu yang telah dilakukan Farida (2016) tentang "Pendidikan Karakter dalam Perspektif Islam". Pendidikan karakter dimaknai sebagai pendidikan nilai, budi pekerti, pendidikan moral, pendidikan watak yang tujuannya untuk mengembangkan kemampuan peserta didik untuk memberikan keputusan baik buruk, mewujudkan kebaikan dalam kehidupan sehari-hari dengan sepenuh hati sebagai citacita luhur dalam dunia pendidikan. Oleh sebab itu, maka pendidikan karakter akan terlaksana jika selaras dengan sistem pendidikan nasional. Penyelengaraan pendidikan sistem pendidikan disebuah negara akan berbeda dengan negara lainnya, karena sistem pendidikan yang diselenggarakan diberbagai negara mempunyai ciri yang sesuai dengan latar belakang budaya masing-masing negara.

Dalam pendidikan karakter harus melibatkan aspek seperti: kognitif, afektif, konatif, dan psikomotorik yang harus dikembangkan sebagai suatu keutuhan (holistik) dalam konteks kultural. Dalam pendidikan Islam, pendidikan karakter merupakan pendidikan yang telah diajarkan Al qur'an, yaitu pendidikan yang mengedepankan Akhlak. Al-Qur'an dengan sangat tegas memberikan solusi yang nyata kepada kita untuk mengembangkan kesadaran spiritual, emosional, dan intelektual yang tidak hanya menjadi teori, tetapi Al qur'an memerintahkan untuk menerjemahkannya dalam kehidupan sehari-hari (Farida: 2016).

Penelitian terdahulu di atas memberikan pemikiran baru bagi penulis tentang pendidikan karakter dalam perspektif islam dengan menginternalisasikan nilai-nilai yang berlandaskan Alqur'an dalam sikap, yang tercermin pada aspek kognitif, afektif, dan konatif.

Lain halnya dengan hasil penelitian yang dilakukan penulis ini. Penulis melihat temuan lain tentang internalisasi nilai-nilai keagamaan dalam membentuk komunikasi keluarga yang islami di era digital ini. Ada peran dari media sosial, sebagai wadah atau media untuk internalisasi nilai-nilai keagamaan ini. Berdasarkan 
hasil wawancara dan observasi yang telah dilakukan, penulis menghasilkan temuan baru dari penelitian yang dibongkar dengan metode studi kasus ini, sebagai berikut:

\section{Peran Orangtua sebagai Komunikator, sangat dominan dalam membentuk Komunikasi Keluarga yang Islami}

Dalam proses komunikasi, kita mengenal keberadaan komunikator, sebagai sumber yang menyampaikan pesan kepada komunikannya, baik dengan menggunakan media maupun secara langsung atau tatap muka. Begitupun halnya, dalam konteks komunikasi keluarga ini terjadinya proses pertukaran pesan dari komunikator kepada komunikan. Terlepas dari siapa yang menjadi komunikator dalam proses komunikasi keluarga ini, para informan menyampaikan bahwa orangtua adalah komunikator yang menentukan dan mendominasi proses komunikasi keluarga tersebut.

Ns, informan penulis yang masih menempuh pendidikan sarjana di salah satu Perguruan Tinggi Negeri di Bandung menyampaikan tentang pentingnya keberadaan orangtua sebagai komunikator yang dominan, terkait dengan internalisasi nilai-nilai keagamaan dalam membentuk komunikasi keluarga yang islami. Ns menegaskan bahwa orangtua sebagai komunikator yang dominan itu memegang peranan penting dalam proses komunikasi keluarga, karena orangtua lah, selayaknya sebagai komunikator pertama, yang mengajarkan nilai-nilai keagamaan tersebut.

Cn, informan kedua dalam penelitian ini, perempuan muda yang telah bekerja di salah satu Bank ini juga menyebutkan adanya orangtua sebagai komunikator yang dominan dalam menyampaikan pesan kepada anak-anaknya, untuk membentuk keluarga yang islami.

Pernyataan dari informan kedua menguatkan penulis tentang adanya peran orangtua sebagai komunikator yang paling dominan dalam internalisasi nilai-nilai keagamaan ini untuk membentuk komunikasi keluarga yang islami. Di samping itu, penulis juga melakukan wawancara kepada salah satu orangtua, yang tengah 
menerapkan nilai-nilai keagamaaan untuk membentuk keluarga yang islami. St, perempuan karir yang telah memiliki dua orang anak ini tengah berbagi kisahnya dalam membesarkan kedua anaknya dengan menerapkan nilai-nilai agama.

St, sebagai seorang ibu juga menceritakan perannya yang mendominasi proses komunikasi keluarganya. Pernyataan di atas juga mempertegas pentingnya keberadaan orangtua sebagai komunikator yang menyampaikan pesan nilai-nilai keagamaan kepada anak-anaknya. Sementara itu, Yjs, pihak ayah, sebagai informan lain dalam penelitian ini, dipilih oleh penulis karena Yjs juga menerapkan nilai-nilai keagamaan dalam keluarganya.

Pernyataan dari informan keempat di atas juga menguatkan penulis tentang pentingnya keberadaan orangtua sebagai komunikator yang dominan, sebagai upaya internalisasi nilai-nilai keagamaan dalam membentuk komunikasi keluarga yang islami di era digital ini. Ternyata, tidak hanya ibu, seorang ayah yang paham tentang pentingnya ajaran agama islam, juga menginginkan anakanaknya berperilaku sesuai dengan nilai-nilai agama islam tersebut.

\section{Nilai-Nilai Keagamaan Yang Ditanamkan Dalam Keluarga Islami Melalui Konteks Pesan Verbal Dan Non Verbal}

Sebagai upaya internalisasi nilai-nilai keagamaan dalam membentuk komunikasi keluarga yang islami ini adalah penyampaian pesan dalam aspek verbal dan aspek non verbal, dari komunikator kepada komunikan, dalam hal ini adalah orangtua kepada anaknya, demi terwujudnya keluarga yang islami.

Sebagaimana konsep dalam ilmu komunikasi, kita mengenal adanya aspek pesan verbal dan aspek pesan non verbal. Begitupun halnya, disampaikan tentang bentuk komunikasi dalam keluarga menurut Novianti (2013:24-25), antara lain, yaitu: a. Komunikasi verbal. Komunikasi merupakan suatu kegiatan antara individu atau kelompok yang mempergunakan bahasa sebagai alat perhubungan. Kegiatan komunikasi verbal menempati frekuensi terbanyak dalam keluarga. Setiap hari orang tua selalu ingin berbincang-bincang kepada anaknya. Dalam perhubungan antara orang tua dan anak akan terjadi interaksi; b. Komunikasi non verbal. Komunikasi non 
verbal suatu ketika bisa berfungsi sebagai penguat komunikasi verbal. Komunikasi non verbal terasa jika secara verbal tidak mampu mengungkapkan sesuatu secara jelas. c. Komunikasi individual. Komunikasi individual atau komunikasi interpersonal adalah komunikasi yang sering terjadi dalam keluarga. Komunikasi yang terjadi berlangsung dalam sebuah interaksi antarpribadi; antara suami dan istri, antara ayah dan anak, antara ibu dan anak, dan antar anak dan anak; dan d. Komunikasi kelompok, hubungan akrab antara orang tua dan anak sangat penting untuk dibina dalam keluarga. Sebenarnya, pertemuan anggota keluarga untuk duduk bersama dalam satu waktu dan kesempatan, sangat penting sebagai simbol keakraban keluarga.

Dalam penelitian ini, penulis melihat adanya penyampaian pesan secara verbal dan non verbal dari pihak orangtua kepada anaknya, sebagai upaya internalisasi nilai-nilai keagamaan tersebut. Para informan penelitian ini juga menyampaikan bahwa dalam proses komunikasi keluarga yang dilakukan, ada pesan verbal berupa nilai-nilai keagamaan itu, dari orangtua kepada anakanaknya. Pernyataan dari Ns, sebagai anak, yang belajar nilai-nilai keagamaan dari pesan verbal dan pesan non verbal yang diberikan oleh orangtuanya. Ns bercerita ada aspek pesan verbal yang disampaikan oleh orangtuanya, misalnya: "nak, jangan lupa hari ini untuk solatnya, puasanya, dan sedekabnya..." Kutipan pesan tersebut merupakan contoh adanya pesan verbal yang diberikan orangtua Ns kepada Ns sebagai anaknya. Begitupun halnya untuk aspek pesan non verbal ini terlihat dari hasil wawancara dengan Ns yang menceritakan ketika Ns memerhatikan pakaian ibunya yang berubah, menjadi islami karena sesuai ajaran nilai-nilai agama islam. Lalu Ns juga mengamati perilaku non verbal Bapaknya dalam aktivitas sehari-harinya.

Jika dilihat dari penuturan Yjs, sebagai ayah yang kerapkali mengajarkan nilai-nilai keagamaan dalam proses komunikasi keluarganya ini, penulis juga dapat menemukan jenis dari konteks pesan verbal dan non verbal yang biasanya dilakukan orangtua kepada anaknya. Yjs menceritakan bahwa pendidikan sekolah juga menjadi elemen penting dalam internalisasi nilai-nilai agama untuk anak-anaknya, sehingga Yjs memilih sekolah pesantren sejenis MTs (Madrasah Tsanawiyah) atau SMP, untuk jenjang pendidikan 
lanjutan dari SD bagi anak-anaknya. Saat ini, Yjs menambahkan bahwa putranya telah masuk ke salah satu MTs di Cilegon, dan jejak ini juga akan diikuti oleh adik-adiknya. Begitupun halnya, informan lain, St juga bercerita bahwa sekolah menjadi point penting untuk pendidikan anaknya, sehingga St dan suaminya sepakat memilih sekolah berbasis islam yang mengajarkan nilai-nilai agama islam bagi anak-anaknya. St bercerita bahwa kedua putrinya juga saat ini tengah menjalani pendidikan sekolah dasar di salah satu sekolah islam yang berada di Bandung.

Sn juga menambahkan bahwa dia menyadari tentang pentingnya menjaga kesehatan juga merupakan bagian dari ajaran agama islam, seperti yang diamatinya dari aktivitas Bapaknya, yang tengah mempraktekkan ajaran islam tersebut, misalnya dengan rajin berolahraga, pola makan yang sehat, dan istirahat yang cukup. Sn mengamati aktivitas orangtua nya ini, yang dimana sebagai bentuk pengajaran internalisasi nilai-nilai keagamaan tentang kesehatan.

Jika dicermati dari hasil wawancara dan observasi yang telah dilakukan, dalam hal ini penulis menemukan adanya internalisasi nilai-nilai keagamaan yang ditanamkan dalam keluarga islam melalui konteks pesan verbal dan non verbal. Konteks pesan verbal dan non verbal ini terdiri dari pesan verbal tentang pendidikan, kesehatan, pergaulan, dan gaya hidup yang islami. Sedangkan pesan non verbal yang terlihat dari pengamatan informan ini juga meliputi tentang pergaulan, gaya hidup yang islami seperti cara berpakaian dalam islam yang dicontohkan oleh orangtua sebagai bentuk pesan non verbal kepada anaknya, dan kesehatan, yang dicontohkan juga oleh orangtua dalam aktivitas sehari-hari yang menjaga kesehatan dengan rajin berolahraga, pola makan yang sehat, dan istirahat yang cukup.

\section{Penggunaan Media Sosial dalam menyebarkan Pesan yang berisi Nilai-Nilai Keagamaan}

Langkah selanjutnya yang menjadi ciri khas sebagai upaya internalisasi nilai-nilai keagamaan dalam membentuk komunikasi keluarga yang islami di era digital, yaitu ditandai dengan penggunaan media digital. Para informan menyampaikan bahwa jenis media digital yang biasanya digunakan sebagai wadah 
komunikasi keluarga yang dilakukannya adalah media sosial Whatsapp Group. Menurut pengakuan para informan, media sosial whatsapp group ini membantu dalam penyampaian pesan verbal secara online tentang berbagai informasi nilai-nilai keagamaan untuk anggota keluarganya. Hal ini dipertegas oleh pernyataan dari Ns yang menyampaikan penggunaan media sosial sebagai wadah komunikasi dalam keluarganya.

St, sebagai orangtua, juga menyampaikan pernyataannya tentang penggunaan media sosial dalam proses komunikasi keluarganya, Sebagai salah satu contoh penggunaan media sosial dalam menyampaikan informasi yang berisi nilai-nilai keagamaan, penulis melampirkan potongan gambar percakapan dalam whatsapp, ketika komunikator menyampaikan pesan yang berisi nilai-nilai keagamaan.

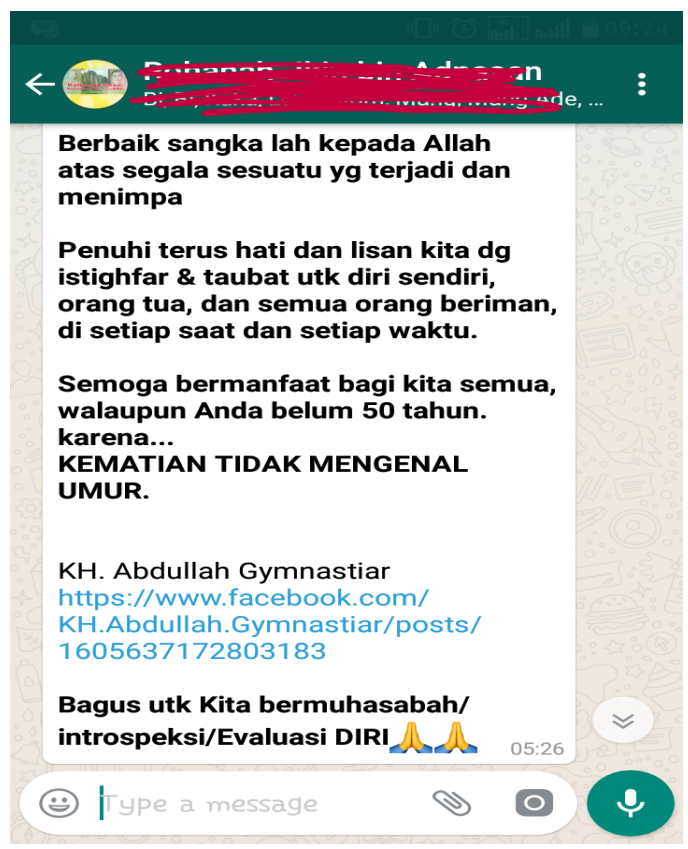

Gambar 1.1

\section{Hasil cuplikan gambar dari salah satu Whatsapp Informan yang mengandung pesan Nilai-Nilai Keagamaan}


Gambar di atas merupakan salah satu contoh yang menunjukkan adanya penggunaan media sosial Whatsapp sebagai wadah menyampaikan informasi yang mengandung pesan nilai-nilai keagamaan. Jika dianalisis, penulis melihat adanya penyampaian informasi dari pihak komunikator kepada komunikan, yang bermaksud ingin menyebarkan pesan tentang nilai-nilai keagamaan yang berisi renungan makna hidup, bahwa kematian itu tidak mengenal umur, hidup yang hanya sebentar ini harus diisi dengan kegiatan positif yang bernilai ibadah, sebagai bekal di akhirat kelak.

\section{Analisis Teori Konstruksi Sosial atas Realitas}

Dalam penelitian ini, penulis menggunakan teori konstruksi sosial atas realitas untuk menganalisis topik penelitian tentang Internalisasi Nilai-Nilai Keagamaan dalam membentuk Komunikasi Keluarga yang Islami di era Digital. Istilah konstruksi atas realitas sosial (social construction of reality) menjadi terkenal sejak diperkenalkan oleh Peter L. Berger dan Thomas Luckman melalui bukunya yang berjudul The Social Construction of Reality: A Treatise in the Sociological of Knowledge (1966). Ia menggambarkan proses sosial melalui tindakan dan interaksinya, dimana individu menciptakan secara terus menerus suatu realitas yang dimiliki dan dialami bersama secara subyektif (Bungin, 2008: 13). Asal usul konstruksi sosial dari filsafat konstruktivisme yang dimulai dari gagasan-gagasan konstruktif kognitif. Menurut Von Glaserfeld, pengertian konstruktif kognitif muncul pada abad ini dalam tulisan Mark Baldwin yang secara luas diperdalam dan disebarkan oleh Jean Piaget. Namun, apabila ditelusuri, sebenarnya gagasangagasan pokok konstruktivisme sebenarnya telah dimulai oleh Giambatissta Vico, seorang epistemolog dari italia, ia adalah cikal bakal konstruktivisme (Bungin, 2008:13).

Teori ini lebih fokus terhadap makna dan penafsiran bersama yang dikonstruksi dalam jaringan masyarakat dan implikasinya pada konstruksi kehidupan organisasi (aturan, norma, nilai, perbuatan yang diterima dalam organisasi (Littlejohn: 2011). Littlejohn menjelaskan bahwa teori sosiokultur kurang memberikan 
perhatian kepada struktur dan bentuk tetapi lebih fokus kepada makna dan penafsiran bersama yang dikonstruksi dalam satu jaringan (organisasi, komunitas, kelompok) dan implikasi dari hasil konstruksi ini terhadap kehidupan organisasi. Inilah yang sering disebut sebagai budaya, yang mencakup nilai bersama, norma, nilai-nilai dan praktik yang lazimnya digunakan dan diterima dalam satu organisasi (Littlejohn: 2011). Jika penulis melakukan analisis pada kajian penelitian ini, terdapat beberapa asumsi dasar dari Teori Konstruksi Sosial Berger dan Luckman, yang ada kaitan erat antara asumsi tersebut dengan fenomena yang terjadi dalam penelitian ini. Adapun asumsi-asumsinya tersebut adalah: 1) Realitas merupakan hasil ciptaan manusia kreatif melalui kekuataan konstruksi sosial terhadap dunia sosial di sekelilingnya. Penulis melihat adanya realitas dalam penelitian ini, tentang pentingnya melakukan internalisasi nilai-nilai keagamaan dalam mewujudkan komunikasi keluarga yang islami di era digital ini. Hal ini tercermin dalam hasil wawancara dengan para informan yang menyatakan pentingnya internalisasi nilai-nilai keagamaan yang ditumbuhkan oleh orangtua kepada anak-anaknya. Rasa kekhawatiran orangtua, salah satunya yang mendasari untuk melakukan internalisasi nilai-nilai keagamaan, yaitu dengan memilih sekolah berbasis islam, sebagai sarana pendidikan untuk anak-anaknya. Dalam penelitian ini, ada realitas, yaitu hasil ciptaan para inforamn kreatif melalui kekuatan konstruksi sosial terhadap dunia sosial di sekelilingnya. 2) Hubungan antara pemikiran manusia dan konteks sosial tempat pemikiran itu timbul, bersifat berkembang dan dilembagakan. Asumsi yang kedua ini terlihat dalam fenomena penelitian yang mencerminkan hubungan antara pemikiran informan dan konteks sosial, sebagai tempat pemikiran itu timbul, yang sifatnya berkembang dan dilembagakan. Misalnya, pemikiran informan untuk melakukan internalisasi nilainilai keagamaan dalam membentuk komunikasi keluarga yang islami. Tempat pemikiran yang timbul ini dilihat pada rasa kekhawatiran para orangtua sebagai informan, yang merasa khawatir dan cemas dengan pergaulan remaja di masa kini. 3) Kehidupan masyarakat itu dikonstruksi secara terus menerus. Asumsi ketiga tentang teori ini, kehidupan masyarakat itu dikonstruksi secara terus menerus, jelas terlihat dalam penelitian ini. Para informan melakukan konstruksi 
atas realitas yang dialaminya, menganggap pentingnya melakukan internalisasi nilai-nilai keagamaan dalam membentuk komunikasi keluarga yang islami di era digital. Sebagai salah satu bagian dari kehidupan masyarakat, fenomena tersebut terus dikonstruksi secara terus menerus, ada masyarakat yang setuju, begitupun sebaliknya, ada juga yang tidak setuju. Inilah makna dari kehidupan masyarakat yang dikonstruksi secara terus menerus.

\section{Kesimpulan}

Berdasarakan hasil penelitian yang telah dilakukan, penulis menghasilkan temuan baru berkaitan dengan adanya upaya internalisasi nilai-nilai keagamaan dalam membentuk komunikasi keluarga yang islami di era digital ini, yaitu Peran orangtua sebagai komunikator, sangat dominan dalam pola komunikasi keluarga yang islami; Nilai-nilai keagamaan yang ditanamkan dalam keluarga islam melalui konteks pesan verbal dan non verbal, mulai dari pendidikan, kesehatan, pergaulan, dan gaya hidup yang islami; Penggunaan media sosial Whatsapp dalam menyebarkan pesan yang berisi nilai-nilai keagamaan kepada anggota keluarga lainnya.

\section{Daftar Pustaka}

Berger, Peter L., Luckmann, Thomas. 1966. The Social Construction of Reality, The Treatise In The Sociology of Reality. Garden City, N.Y. : Doubleday.

Media Group 2007. Penelitian Kualitatif. Jakarta: Kencana Prenada . 2008. Konstruksi Sosial Media Massa: Kekuatan Pengaruh Media Massa, Iklan, Televisi, dan Keputusan Konsumen Serta Kritik Terhadap Peter L. Berger \& Thomas Luckmann. Jakarta: Kencana.

Bungin, Burhan. 2007. Sosiologi Komunikasi: Teori, Paradigma, dan Diskursus Teknologi Komunikasi di Masyarakat. Jakarta: Kencana Prenada Media Group. 
Carkhuff, Rober R. 1983. The Art of Helping. Massachusetss: Human Resource Devloment Press. Inc.

Cresswell, John W. 1998. Research Design, Qualitative \& Quantitative Approaches. Yogyakarta: Pustaka Pelajar.

Diding Nurdin. 1999. Pengaruh Kepemimpinan Kyai terhadap Kualitas Sumber Daya Manusia: Studi Analisis Figur Kyai dalam membentuk Pribadi Muslim Seutuhnya di Pondok Pesantren Daarut Tauhid Bandung. Tesis PPS IKIP Bandung.

Djamarah, Syaiful Bahri. 2004. Pola Komunikasi Orang Tua dan Anak dalam Keluarga. Sebuah Prespektif Pendidikan Islam. Bandung: Rineka Cipta

Farida, S. (2016). PENDIDIKAN KARAKTER DALAM PRESPEKTIF ISLAM. KABILAH: Journal of Social Community, 1(1), 198207.

Goode, W.J. 2007. Sosiologi Keluarga. Jakarta: Bumi Aksara.

K. Yin, Robert. 2002. Studi Kasus (Desain dan Metode). Jakarta. PT. Raja Grafindo Persada.

Littlejohn, Stephen W \& Karen A. Foss. 2011. Teori Komunikasi, edisi 9. Jakarta: Salemba Humanika

Moch.Nazir. 2003. Metode Penelitian. Jakaarta: Salemba Empat.

Mulyana, Deddy. 2008. Metodologi Penelitian Komunikasi. Bandung: Remaja Rosda Karya.

Novianti, Evi. 2013. Pola Komunikasi Keluarga Antar Budaya. Bandung: Arsad Press

Sugiyono. 2011. Metode Penelitian Kuantitatif, Kualitatif dan R\&D. Bandung: Alfabeta

Supriyatno, T. (2012). Model Internalisasi Nilai-Nilai Keagamaan di Ma'had Sunan Ampel Al-Ali UIN Malang. El-QUDWAH.

Tubbs, Stewart L \& Sylvia Moss. 2005. Human Communication: Konteks-Konteks Komunikasi, Editor: Deddy Mulyana. Bandung: PT Remaja Rosda Karya.

Wijayanti, Y. T. 2015. Pola Komunikasi Keluarga dalam Membangun Akhlakul Karimah. CHANNEL Jurnal Komunikasi, 3(2). 


\title{
Geliat Puritanisme Islam di Indonesia: Menyibak Tabir di Balik Gerakan Majelis Tafsir Al-Qur'an (MTA) dalam Perspektif Sosiologis
}

\author{
Ilyya Muhsin, Muhammad Gufron \\ IAIN Salatiga \\ ilyya_mubsin@yaboo.com
}

\begin{abstract}
Purification movements conducted by MTA are very interesting to be studied. Although the form of a charismatic foundation with leadership, MTA puritan da'wah like a social organization, because it has an active organizational structure moving through various organs. Therefore, there is an interesting side to discussing this MTA in a sociological perspective, with the theory of social movements. The results can be seen from three aspects of social movements: first, taking advantage of political opportunities in the form of silatnas and early morning studies. Second, mobilizing resources, consisting of moral resources, namely the Qur'an-hadith and figures; cultural resources with various MTA business charities; human resources, with a structured cadre system; well-structured social-organizational resources, and tremendous financial resources. Third, arrange the movement process in solving various diseases of the people with the right solution for the MTA
\end{abstract}

Keywords: MTA, social movement, Purification.

\begin{abstract}
Abstrak
Gerakan purifikasi yang dilakukan MTA sangat menarik untuk dikaji. Meski berbentuk yayasan dengan kepemimpinan yang kharismatik, MTA berdakwah puritan seperti organisasi sosial, karena memiliki struktur organisasi yang aktif bergerak melalui berbagai organnya. Karena itu, ada sisi menarik membahas MTA ini dalam perspektif sosiologis, yakni dengan teori gerakan sosial. Hasilnya dapat dilihat dari tiga aspek gerakan sosial: pertama, memanfaatkan peluang politik dalam bentuk silatnas dan kajian ahad pagi. Kedua, memobilisasi sumber daya, yang terdiri dari sumber daya moral, yaitu Al-Qur'an-hadis dan figur; sumber daya kultural dengan berbagai amal usaba MTA; sumber daya manusia, dengan sistem kaderisasi terstruktur; sumber daya sosial-organisasi yang terstruktur baik, dan sumber daya finansial yang luar biasa. Ketiga, menyusun proses gerakan dalam menyelesaikan berbagai penyakit umat dengan solusi yang tepat bagi MTA.
\end{abstract}

Kata Kunci: MTA, gerakan sosial, Purifikasi.

Permalink/DOI: http://dx.doi.org/10.18326/infsl3v12i1.213-238 